\title{
МОРФОЛОГІЧНА ДІАГНОСТИКА ІНФЕКЦІЙНИХ УРАЖЕНЬ СЕРЕД ВІЛ-ІНФІКОВАНИХ ПАЦІЄНТІВ 3 ПАТОЛОГІЄЮ ОРГАНІВ ГРУДНОЇ ПОРОЖНИНИ
}

\author{
๑І. В. Ліскіна, О. О. Мельник, Л. М. Загаба, С. Д. Кузовкова, О. Л. Мельник \\ Державна установа «Національний інститут фтизіатрії і пульмонології імені Ф. Г. Яновського \\ НАМН України», Київ
}

РЕЗЮМЕ. ВІЛ-інфекція приводить до постійного зростання кількості осіб із опортуністичними захворюваннями та летальності від них. Частота розвитку захворювань органів дихання - більше $60 \%$, при цьому найчастіше діагностується туберкульоз. Діагностичні можливості стосовно опортуністичних хвороб залишаються обмеженими. Окрім того, наразі більш ніж у 50 \% пацієнтів має місце поєднання різних вторинних захворювань, що призводить до зростання тяжкості їх перебігу, проблем діагностики та лікування.

Мета - встановити діагностичну ефективність комплексного застосування різних методів гістологічного дослідження для верифікації етіології інфекційних уражень органів грудної порожнини на тлі ВІЛ-інфекції.

Матеріал і методи. Групу дослідження склав 31 випадок вторинних інфекційних уражень органів грудної порожнини у ВІЛ-інфікованих хворих. Перш за все проводили традиційне гістологічне дослідження. Додатково застосовували гістохімічні методики: Ціль - Нільсен, флуоресцентний метод, метод Гоморі - Гроккота та ШЙКреакцію з альціановим синім, а також імуногістохімічне дослідження для виявлення мікобактеріальних антигенів з двома поліклональними антитілами до M. tuberculosis.

Результати. За результатами комплексного гістологічного дослідження діагностовано 15 (48,4 \%) випадків туберкульозного процесу. Зіставлення попереднього та заключного клінічних діагнозів усіх випадків нашого дослідження показало, що лише у 3 випадках (9,7 \%) отримано підтвердження попереднього клінічного діагнозу, у 9 випадках (29,0 \%) клінічний діагноз був уточнений та у 12 випадках (38,7 \%) встановлено діагноз. Ще в 5 випадках $(16,1 \%)$ попередній клінічний діагноз виявився хибним та був змінений. І лише у 2 (6,5 \%) випадках остаточний діагноз не було встановлено. Таким чином, в 25 випадках $(80,6$ \%) встановлено розвиток грибкової інфекції та у 15 випадках (48,4 \%) діагностовано туберкульоз. Загалом у $16(51,6$ \%) випадках виявлено асоціацію різних вторинних інфекцій.

Висновок. При проведенні морфологічної діагностики у ВІЛ-інфікованих пацієнтів із вторинними інфекційними ураженнями органів грудної порожнини доцільно застосовувати низку спеціальних гістохімічних методів дослідження уражених тканин. У 67,7 \% випадків при розширеному морфологічному дослідженні початковий патогістологічний висновок був уточнений або повністю змінений. Загальна ефективність комплексного морфологічного дослідження склала 93,5\%.

КЛючОВІ СлОВА: ВІЛ-інфекція; туберкульоз; опортуністичні захворювання; гістологічне дослідження; діагностика.

Вступ. ВІЛ-інфекція залишається однією з найактуальніших соціальних, епідеміологічних та медичних проблем XXI століття, причому вона пов'язана з постійно зростаючою кількістю ВІЛінфікованих осіб із вторинними (опортуністичними) захворюваннями та зростанням летальності від них $[1,2]$. Опортуністичні захворювання при ВІЛ-інфекції - це досить своєрідна група хвороб, які відрізняються за низкою властивостей (частотою розвитку, клінічним перебігом, терапевтичними заходами) від інфекцій, які розвиваються при інших імунодефіцитних станах [3]. Відомо, що 3 прогресуванням імунодефіциту у ВІЛ-інфікованих пацієнтів спостерігається розвиток вторинних захворювань різної етіології та локалізації. При цьому частота виникнення хвороб органів дихання, зокрема нижніх дихальних шляхів, зростає із поглибленням рівня імунодефіциту - більше $60 \%[4,5]$. Згідно з даними літератури, у 25-60 \% ВІЛ-позитивних хворих уражаються саме легені. Найчастіше з опортуністичних захворювань органів дихання діагностують туберкульоз (ТБ) (до 66,5%), що може з'явитися на будь-якій стадії ВІЛ-інфекції і при будь-якій кількості $\mathrm{CD}^{4+}$-лімфоцитів [6].

Відомо, що при ВІЛ-інфекції основною клітиною-мішенню $\epsilon$ лімфоцит (зокрема, Т-хелперна ланка імунного захисту), із прогресуванням захворювання кількість лімфоцитів прогресивно зменшується, що, в свою чергу, призводить до зниження рівня CD4-клітин. У термінальних стадіях хвороби (стадія СНІДу) імунні сили організму не можуть чинити опір навіть маловірулентним, умовно патогенним мікроорганізмам, і розвиток опортуністичних інфекцій, зокрема грибкової, які зазвичай не розвиваються в здоровому організмі, може призводити до летальних наслідків $[1,2,7,8]$.

Терміни розвитку різних опортуністичних захворювань тісно пов'язані зі ступенем тяжкості імунодефіциту: більшості з них притаманна певна черговість. Найпершим клінічним показником прогресування імунодефіциту вважають кандидоз слизових оболонок аж до ураження стравоходу та кишечника при поглибленні імунодефіциту. Далі характерний розвиток бактеріальних пнев- 
Огляди літератури, оригінальні дослідження, погляд на проблему, випадок з практики, короткі повідомлення моній, ТБ легень, герпетичні враження. При наростанні порушень імунної системи часто розвиваються локальна саркома Капоші (СК), лімфоми, пневмоцистна пневмонія (ПП), тяжкі грибкові інфекції, позалегеневий та генералізований ТБ. Потім зазвичай виникають рецидиви ПП, СК, криптококовий менінгіт, токсоплазмозний енцефаліт, цитомегаловірусна інфекція, атипові мікобактеріози. Це далеко не весь спектр вторинних хвороб, які можуть розвинутися у ВІЛ-інфікованих на тлі прогресування імунодефіциту. Окрім того, наразі більш аніж у 50 \% пацієнтів має місце поєднання різних вторинних захворювань, що призводить до зростання тяжкості їх перебігу, проблем діагностики та лікування. Спостерігається також зростання резистентності багатьох опортуністичних збудників до наявних медикаментів [3].

Залежно від виду збудника, ВІЛ-асоційовані інфекції поділяють на декілька груп: протозойні (паразитарні), бактеріальні (ТБ, нетуберкульозні мікобактеріози, бактеріальна неспецифічна мікрофлора), грибкові (криптококоз, криптоспорідіоз, пневмоцитоз, кандидоз, аспергильоз), вірусні (цитомегаловірус) і поєднані (мікст) інфекції $[2,3,9]$.

Згідно з опублікованими даними російських досліджень, останніми роками основними вторинними захворюваннями у хворих із встановленим діагнозом СПІДу $є$ ТБ (його частка складає більше $60 \%)$, ПП (5,6\%), кандидоз стравоходу і внутрішніх органів (7\%), маніфестна ЦМВІ (більше 1,5 \%), церебральний токсоплазмоз (1,5\%), лімфопроліферативні захворювання (більше 1,5\%), рецидивні бактеріальні пневмонії (близько 2 \%). Значну питому вагу складає синдром виснаження, обумовлений впливом ВІЛ (8\%) [3].

Навіть через 35 років з початку епідемії ВІЛінфекції діагностичні можливості стосовно опортуністичних уражень залишаються обмеженими через відсутність патогномонічних клінічних симптомів і надійних лабораторних критеріїв [3, 10]. Рутинні серологічні методи на практиці малопридатні, що зазвичай обумовлено вираженим імунодефіцитом у таких осіб [10]. Зокрема, виявити самі структури гриба в зрізах тканин при традиційному гістологічному дослідженні далеко не завжди буває просто, тому на практиці часто використовують додаткові специфічні гістологічні методики $[1,10,11]$. Відомо, що й морфологічні прояви туберкульозної інфекції при ВІЛ-інфекції втрачають типові риси, інколи сам процес характеризується швидкопрогресуючим перебігом. Гострота і швидкість розвитку ТБ можуть нагадувати перебіг неспецифічної бактеріальної інфекції. Окрім того, при глибокому імунодефіциті перебіг туберкульозної інфекції часто супроводжується розвитком інших вторинних захворювань, які маскують клінічну картину ТБ і ще більше ускладнюють діагностику [3].

Як було встановлено при автопсійних дослідженнях, макроскопічно картина при грибковій інфекції найчастіше малоспецифічна, іноді візуально подібна з ураженнями, викликаними мікобактеріями туберкульозу (МБТ) [1]. Подібні макроскопічні зміни спостерігаються і при мікобактеріозах. Клінічні симптоми при мікобактеріозах, хоча й досить характерні для захворювання, проте не патогномонічні. Рядом авторів відзначено, що лихоманка і втрата ваги виникають задовго до бактеріємії. Зміни, що виявляються при лабораторних та інструментальних дослідженнях пацієнтів з мікобактеріальною інфекцією, також досить неспецифічні. Однак зазначають, що, на відміну від ТБ, для мікобактеріальної інфекції не характерно ураження серозних оболонок і ЦНС. Мікроскопічна картина при мікобактеріозах часто потребує диференціювання з хронічним запальним процесом із макрофагальною реакцією, гранульоматозними захворюваннями, метастазами світлоклітинного раку. Саме тому при підозрі на ТБ або мікобактеріозі принципове значення має комплексне дослідження біопсійного або операційного матеріалу з обов'язковим проведенням гістобактеріоскопії з фарбуванням зразків тканини за Ціль - Нільсеном (Ц-Н). При мікобактеріозах гістобактеріоскопічно кислотостійкі бактерії (КСБ) зазвичай виявляють локалізованими в цитоплазмі макрофагів у величезній кількості, що не піддається обрахунку. При ТБ КСБ частіше локалізовані в цитоплазмі нейтрофільних лейкоцитів або дифузно розміщуються в казеозно-некротичних масах, і кількість їх значно менша, порівняно $з$ КСБ при мікобактеріозі $[2,3]$.

Отже, діагностика вторинних інфекцій на тлі ВІЛ-СНІДу є вкрай актуальним завданням сьогодення.

Мета - встановити діагностичну ефективність комплексного застосування різних методів гістологічного дослідження для верифікації етіології інфекційних уражень органів грудної порожнини на тлі ВІЛ-інфекції.

Матеріал і методи дослідження. У групу дослідження увійшов 31 випадок вторинного інфекційного ураження органів грудної порожнини ВІЛ-інфікованих хворих, госпіталізованих у клініку ДУ «Національний інститут фтизіатрії і пульмонології імені Ф. Г. Яновського НАМН України». Серед них було 27 випадків різної патології легень, 2 випадки уражень плеври, 1 випадок лімфаденопатії та 1 випадок поєднаного ураження легень i лімфатичних вузлів. У всіх цих випадках хворим були виконані малоінвазивні діагностичні процедури із біопсією уражених тканин або великі опе- 
Огляди літератури, оригінальні дослідження, поглядн ративні втручання. У низці випадків досліджували матеріал автопсії. В усіх спостереженнях перш за все проводили традиційне гістологічне дослідження із забарвленням зразків тканини гематоксиліном і еозином [12]. За клінічної підозри або при наявності ознак гранульоматозного запального процесу при традиційному гістологічному дослідженні додатково застосовували гістохімічні методики виявлення КСБ у тканинах за Ц-Н та флуоресцентним методом (Tb-fluor) (по 21 випадку) $[13,14]$. При підозрі на наявність грибкової інфекції проводили гістологічну ідентифікацію збудника із застосуванням методу Гоморі - Гроккота за протоколом, а за необхідності, для виявлення гістоплазми, етап окиснення в йодній кислоті було подовжено до 60 хвилин при температурі 56$60^{\circ} \mathrm{C}$ (загалом 30 випадків) [15-17]. Також була застосована ШЙК-реакція з альціановим синім, яка дозволяє більш чітко виявляти капсулу клітин деяких видів грибів, яка складається із гетерополісахаридів та набуває специфічного забарвлення (29 випадків) $[15,17]$. Додатково проведене імуногістохімічне дослідження для виявлення мікобактеріальних антигенів у тканинах із використанням поліклонального антитіла до M. Tuberculosis (IГX) (PA1-7231, виробництва ThermoScientific, США, робоче розведення 1:2000, з системою візуалізації UltraVision Quanto) та поліклонального антитіла до M. tuberculosis з флуоресцентною міткою (FITC) (PA1-73134, виробництва ThermoScientific, США, робоче розведення 1:25 (по 19 випадків) [18].

Мікроскопічне дослідження проводили на мікроскопах Olympus BX51 з флуоресцентною приставкою Olympus U-RFL-T у діапазоні довжини хвилі збуджуючого світла 461-489 нм і випромінюючого світла 497-532,5 нм та Olympus BX41, роблему, випадок з практики, короткі повідомлення робочі збільшення $\times 100, \times 200, \times 400, \times 1000$. Статистичну обробку даних виконували за допомогою ліцензійних програмних продуктів, що входять у пакет Microsoft Office Professional 2000 (Excel).

Результати й обговорення. На момент госпіталізації ВІЛ-інфікованих пацієнтів, у яких в стаціонарі з діагностичною метою було отримано біоматеріал для гістологічного дослідження, встановлені такі попередні клінічні діагнози: різні форми ТБ легень - 9 випадків (29,0 \%), двобічні вогнищеві зміни у легенях - 4 випадки (12,9\%), утворення в легенях - 4 випадки (12,9\%), дисемінований процес нез' ясованого ґенезу - 5 випадків $(16,1 \%)$, ПП5 випадків (16,1 \%) та в 4-х випадках (12,9 \%) діагностовано інші захворювання органів дихання. Тобто, щонайменше у 13 випадках (41,9 \%) за клініко-лабораторними та рентгенологічними даними етіологія процесу була невідомою.

У результаті традиційного гістологічного дослідження були отримані такі патогістологічні висновки: різні форми ТБ легень - 9 випадків (29,0\%), ПП - 8 випадків (25,8 \%), генералізований криптококоз - 3 випадки $(9,7 \%)$ та в 1 випадку (3,2 \%) було діагностовано інвазивний аспергільоз. У 3 випадках $(9,7 \%)$ зроблено висновок про наявність продуктивного інфекційного запального процесу без уточнення збудника. Ймовірність поєднання туберкульозної та грибкової інфекцій була запідозрена в 7 випадках (22,6\%).

Наступним етапом морфологічного дослідження було застосування низки додаткових спеціальних гістохімічних та імуногістохімічних методів для уточнення природи інфекційних уражень легень та інших органів грудної порожнини (табл. 1).

Таблиця 1. Розподіл позитивних результатів різних гістологічних досліджень залежно від висновку при традиційному гістологічному дослідженні із забарвленням тканини гематоксиліном і еозином

\begin{tabular}{|c|c|c|c|c|c|c|}
\hline \multirow{2}{*}{$\begin{array}{c}\text { Патогістологічний } \\
\text { висновок } \\
\text { (забарвлення } \\
\text { гематоксиліном і } \\
\text { еозином) }\end{array}$} & \multirow{2}{*}{$\begin{array}{l}\text { Кількість } \\
\text { випадків }\end{array}$} & \multicolumn{5}{|c|}{$\begin{array}{c}\text { Допоміжні морфологічні дослідження, } \\
\text { кількість позитивних результатів, абс. (\%) }\end{array}$} \\
\hline & & $\begin{array}{c}\text { метод Гоморі-Гроккота } \\
\text { та/або ШЙК-реакція з } \\
\text { альціановим синім }\end{array}$ & $\begin{array}{l}\text { метод Ціль- } \\
\text { Нільсена }\end{array}$ & $\begin{array}{c}\text { флуорес- } \\
\text { центний } \\
\text { метод } \\
\end{array}$ & $\begin{array}{c}\text { імуногіс- } \\
\text { тохімічний } \\
\text { метод } \\
\end{array}$ & $\begin{array}{c}\text { імуногістохі- } \\
\text { мічний FITC } \\
\text { метод } \\
\end{array}$ \\
\hline 1 & 2 & 3 & 4 & 5 & 6 & 7 \\
\hline $\begin{array}{l}\text { Різні форми } \\
\text { туберкульозного } \\
\text { ураження }\end{array}$ & $\begin{array}{c}9 \\
(29,0 \pm 8,2)\end{array}$ & $\begin{array}{c}6 \\
(19,4 \pm 7,1)\end{array}$ & $\begin{array}{c}5 \\
(23,8 \pm 9,3)\end{array}$ & $\begin{array}{c}6 \\
(28,6 \pm 9,9)\end{array}$ & $\begin{array}{c}9 \\
(47,4 \pm 11,5)\end{array}$ & $\begin{array}{c}6 \\
(31,6 \pm 10,7)\end{array}$ \\
\hline $\begin{array}{l}\text { Пневмоцистна } \\
\text { пневмонія }\end{array}$ & $\begin{array}{c}8 \\
(25,8 \pm 7,9) \\
\end{array}$ & $\begin{array}{c}6 \\
(19,4 \pm 7,1)\end{array}$ & $\begin{array}{c}1 \\
(4,8 \pm 4,6)\end{array}$ & $\begin{array}{c}1 \\
(4,8 \pm 4,6) \\
\end{array}$ & $\begin{array}{c}1 \\
(5,3 \pm 5,1)\end{array}$ & $\begin{array}{c}1 \\
(5,3 \pm 5,1) \\
\end{array}$ \\
\hline $\begin{array}{l}\text { Поєднання } \\
\text { туберкульозу та } \\
\text { грибкової інфекції* }\end{array}$ & $\begin{array}{c}7 \\
(22,6 \pm 7,5)\end{array}$ & $\begin{array}{c}5 \\
(16,1 \pm 6,6)\end{array}$ & $\begin{array}{c}6 \\
(28,6 \pm 9,9)\end{array}$ & $\begin{array}{c}6 \\
(28,6 \pm 9,9)\end{array}$ & $\begin{array}{c}5 \\
(26,3 \pm 10,1)\end{array}$ & $\begin{array}{c}5 \\
(26,3 \pm 10,1)\end{array}$ \\
\hline $\begin{array}{l}\text { Продуктивний } \\
\text { інфекційний } \\
\text { запальний процес }\end{array}$ & $\begin{array}{c}3 \\
(9,7 \pm 5,3)\end{array}$ & $\begin{array}{c}3 \\
(9,7 \pm 5,3)\end{array}$ & $\begin{array}{c}1 \\
(4,8 \pm 4,6)\end{array}$ & $\begin{array}{c}2 \\
(9,5 \pm 6,4)\end{array}$ & $\begin{array}{c}2 \\
(10,5 \pm 7,0)\end{array}$ & $\begin{array}{c}1 \\
(5,3 \pm 5,1)\end{array}$ \\
\hline
\end{tabular}


Огляди літератури, оригінальні дослідження, погляд на проблему, випадок з практики, короткі повідомлення

Продовження табл. 1

\begin{tabular}{|c|c|c|c|c|c|c|}
\hline 1 & 2 & 3 & 4 & 5 & 6 & 7 \\
\hline $\begin{array}{l}\text { Генералізований } \\
\text { криптококоз }\end{array}$ & $\begin{array}{c}3 \\
(9,7 \pm 5,3)\end{array}$ & $\begin{array}{c}3 \\
(9,7 \pm 5,3)\end{array}$ & $\begin{array}{c}1 \\
(4,8 \pm 4,6)\end{array}$ & $\begin{array}{c}1 \\
(4,8 \pm 4,6)\end{array}$ & $\begin{array}{c}2 \\
(10,5 \pm 7,0)\end{array}$ & $\begin{array}{c}1 \\
(5,3 \pm 5,1)\end{array}$ \\
\hline $\begin{array}{l}\text { Інвазивний } \\
\text { аспергільоз }\end{array}$ & $\begin{array}{c}1 \\
(3,2 \pm 3,2)\end{array}$ & $\begin{array}{c}1 \\
(3,2 \pm 3,2)\end{array}$ & 0 & 0 & 0 & 0 \\
\hline Усього досліджень & 31 & 31 & 21 & 21 & 19 & 19 \\
\hline
\end{tabular}

Примітки. 1. * - грибкова інфекція без уточнення виду гриба; 2. «0»- не досліджували.

За результатами застосування гістохімічних методик на виявлення грибкової інфекції (метод Гоморі - Гроккота та ШЙК-реакція з альціановим синім) у 9 випадках (29,0 \%) було підтверджено гістологічний діагноз, встановлений при традиційному гістологічному дослідженні, ще у 16 випадках (51,6 \%) гістологічний висновок був уточнений. У 5 випадках (16,1 \%) попередній патогістологічний висновок виявився хибним, діагноз було змінено, в тому числі в 4 (12,9 \%) випадках діагноз мікобактеріальної інфекції був змінений на грибкову інфекцію як основну легеневу патологію, а в 1 випадку, навпаки, спочатку клінічно була діагностована ПП як основний діагноз, натомість застосування відповідних методик виключило цей діагноз. I лише в 1 випадку (3,2 \%) остаточний діагноз не був установлений, навіть застосування додаткових гістохімічних методик не дало змоги зробити конкретний висновок про природу патології.

Застосування вищезазначених гістохімічних методів забарвлення продемонструвало, що у тканині легень найчастіше визначалися кокові форми різних грибів - 25 випадків $(80,6 \%)$ та диморфні структури гриба - 10 випадків (32,3 \%). Досить рідко виявлялися нитчасті форми грибів - 2 випадки (6,5 \%). Лише в 4 (12,9\%) випадках чіткі структури грибів не були виявлені.

Згідно з результатами застосування гістохімічних методик щодо виявлення мікобактерій туберкульозу (методи Ц-Н та Tb-fluor, 21 випадок), отримано позитивний результат у $14(66,7 \%)$ та у 16 (76,2 \%) випадках відповідно.

За результатами імуногістохімічного дослідження щодо виявлення мікобактеріальних антигенів у тканинах (19 випадків) із використанням двох поліклональних антитіл до M. Tuberculosis (FITC та ІГХ-метод) у 14 (73,7 \%) та 19 (100\%) випадках відповідно було отримано позитивний результат.

Загалом, у 18 (81,8 \%) випадках були застосовані одночасно всі чотири методики для виявлення МБТ та мікобактеріальних антигенів, із них в 11 випадках $(61,1 \%)$ результат був позитивний за всіма вищезгаданими методиками.

Отже, за результатами комплексного гістологічного дослідження діагностовано 15 (48,4 \%) ви- падків туберкульозного процесу. Вони відповідали таким клініко-морфологічним формам ТБ-генералізований ТБ (6 випадків, 40,0\%), дисемінований ТБ легень (4 випадки, 26,7%), інфільтративний (2 випадки, 13,3 \%) та по 1 випадку (6,7 \%) - туберкульома-казеома, фіброзно-кавернозний ТБ легень і залишкові зміни ТБ у вигляді дрібних туберкульом.

Зіставлення попереднього та заключного клінічних діагнозів усіх випадків нашого дослідження показало, що завдяки комплексному морфологічному дослідженню, лише у 3 випадках (9,7 \%) отримано підтвердження попереднього клінічного діагнозу, у 9 випадках $(29,0$ \%) клінічний діагноз був уточнений та у 12 випадках (38,7 \%) встановлений. Ще в 5 випадках $(16,1 \%)$ попередній клінічний діагноз виявився хибним та був змінений. I лише у 2 (6,5 \%) випадках остаточний діагноз не було встановлено, з них в 1 випадку (3,2 \%) залишилася підозра на наявність грибкової інфекції. Результати наведено в таблиці 2.

У результаті проведеного комплексного морфологічного дослідження в 25 випадках (80,6 \%) встановлено розвиток грибкової інфекції, причому в 11 випадках (35,5 \%) вона розвинулася в якості основної вторинної хвороби та у 4 випадках (12,9 \%) - у якості конкуруючої основної вторинної хвороби. У 15 випадках (48,4 \%) діагностовано ТБ, із них у 14 (45,2 \%) він виступав у якості основного вторинного захворювання. Причому, загалом у 16 (51,6 \%) випадках виявлено асоціацію різних вторинних інфекцій.

Загальна ефективність комплексної морфологічної діагностики склала 93,5 \%.

Представлений опис етапів морфологічного дослідження наочно демонструє тяжкість діагностики вторинних інфекцій не лише за клініко-лабораторними та рентгенологічними даними, а й при гістологічному дослідженні біопсійного, операційного та автопсійного матеріалу. Цей факт неодноразово підкреслюється у багатьох подібних роботах останніх десятиріч $[9,19,20]$. Наприклад, відомо, що рентгенологічний синдром змін легеневої тканини типу «матового скла» морфологічно пов'язаний $з$ клітинно-рідинною інфільтрацією септального простору інтерстицію та помірною альвеолярною ексудацією з мультифокальним 
Огляди літератури, оригінальні дослідження, погляд на проблему, випадок з практики, короткі повідомлення Таблиця 2. Зіставлення попереднього та заключного клінічних діагнозів із урахуванням результатів розширеного гістологічного дослідження уражених тканин органів грудної порожнини

\begin{tabular}{|c|c|c|c|}
\hline $\begin{array}{l}\text { Попередній } \\
\text { клінічний діагноз: }\end{array}$ & $\begin{array}{c}\text { Кількість } \\
\text { випадків, абс. } \\
(\%) \\
\end{array}$ & Заключний клінічний діагноз: & $\begin{array}{c}\text { Кількість } \\
\text { випадків, абс. } \\
(\%) \\
\end{array}$ \\
\hline \multirow[t]{4}{*}{ Туберкульоз } & \multirow[t]{4}{*}{$9(29,0 \pm 8,2)$} & • Поєднання туберкульозу та грибкової інфекції & $\begin{array}{c}5 \\
(16,1 \pm 6,6) \\
\end{array}$ \\
\hline & & • Грибкова інфекція & $\begin{array}{c}2 \\
(6,5 \pm 4,4)\end{array}$ \\
\hline & & • Поєднання грибкової та вірусної інфекцій & $\begin{array}{c}1 \\
(3,2 \pm 3,2)\end{array}$ \\
\hline & & $\begin{array}{l}\text { • Поєднання туберкульозу, грибкової та вірусної } \\
\text { інфекцій }\end{array}$ & $\begin{array}{c}1 \\
(3,2 \pm 3,2) \\
\end{array}$ \\
\hline \multirow[t]{3}{*}{$\begin{array}{l}\text { Пневмоцистна } \\
\text { пневмонія* }\end{array}$} & \multirow[t]{3}{*}{$5(16,1 \pm 6,6)$} & • Пневмоцистна пневмонія & $\begin{array}{c}2 \\
(6,5 \pm 4,4) \\
\end{array}$ \\
\hline & & $\begin{array}{l}\text { • Поєднання пневмоцистної пневмонії та вірусної } \\
\text { інфекції }\end{array}$ & $\begin{array}{c}1 \\
(3,2 \pm 3,2)\end{array}$ \\
\hline & & • Поєднання мікобактеріозу та вірусної інфекції & $\begin{array}{c}2 \\
(6,5 \pm 4,4) \\
\end{array}$ \\
\hline \multirow{4}{*}{$\begin{array}{l}\text { Дисемінований } \\
\text { процес неясного } \\
\text { ґенезу в легенях }\end{array}$} & \multirow[t]{4}{*}{$5(16,1 \pm 6,6)$} & • Грибкова інфекція & $\begin{array}{c}1 \\
(3,2 \pm 3,2) \\
\end{array}$ \\
\hline & & • Поєднання туберкульозу та грибкової інфекції & $\begin{array}{c}1 \\
(3,2 \pm 3,2) \\
\end{array}$ \\
\hline & & • Аспіраційна пневмонія & $\begin{array}{c}1 \\
(3,2 \pm 3,2)\end{array}$ \\
\hline & & • Без остаточного діагнозу & $\begin{array}{c}2 \\
(6,5 \pm 4,4) \\
\end{array}$ \\
\hline \multirow[t]{2}{*}{$\begin{array}{l}\text { Двобічні вогнищеві } \\
\text { зміни легень }\end{array}$} & \multirow[t]{2}{*}{$4(12,9 \pm 6,0)$} & • Грибкова інфекція & $\begin{array}{c}3 \\
(9,7 \pm 5,3)\end{array}$ \\
\hline & & • Поєднання туберкульозу та грибкової & $\begin{array}{c}1 \\
(3,2 \pm 3,2) \\
\end{array}$ \\
\hline \multirow[t]{2}{*}{ Утворення в легенях } & \multirow[t]{2}{*}{$4(12,9 \pm 6,0)$} & • Грибкова інфекція & $\begin{array}{c}1 \\
(3,2 \pm 3,2) \\
\end{array}$ \\
\hline & & • Поєднання туберкульозу та грибкової інфекції & $\begin{array}{c}3 \\
(9,7 \pm 5,3) \\
\end{array}$ \\
\hline \multirow[t]{3}{*}{$\begin{array}{l}\text { Інші захворювання } \\
\text { органів дихання }\end{array}$} & \multirow[t]{3}{*}{$4(12,9 \pm 6,0)$} & • Грибкова інфекція & $\begin{array}{c}2 \\
(6,5 \pm 4,4) \\
\end{array}$ \\
\hline & & • Туберкульоз & $\begin{array}{c}1 \\
(3,2 \pm 3,2) \\
\end{array}$ \\
\hline & & • Поєднання туберкульозу та грибкової інфекції & $\begin{array}{c}1 \\
(3,2 \pm 3,2) \\
\end{array}$ \\
\hline Усього досліджень & 31 & & 31 \\
\hline
\end{tabular}

Примітка. * - пневмоцистна пневмонія окремо виділена з грибкових уражень, оскільки була діагностована клінічно.

або дифузним розповсюдженням у легенях, що досить типово для хворих з ВІЛ-інфекцією з вираженою імуносупресією при розвитку не лише ПП, а й інших опортуністичних інфекцій, таких як цитомегаловірусна або герпетична інфекції тощо [3, 20]. За висновками інших практиків-науковців, у всіх випадках розвитку СНІД-асоційованих хвороб органів дихання обов'язковою процедурою має бути фарбування патологічного матеріалу за Ц-Н, враховуючи різноманітність клінічної та морфологічної картини ТБ у ВІЛ-інфікованих на різних стадіях ко-інфекції та частоту її розвитку [21].

Використовуючи лише традиційне забарвлення тканини гематоксиліном і еозином, при гіс- тологічному дослідженні, наприклад, у тканині легень, можна виявити великі клітини із внутрішньоядерними базофільними включеннями типу "совиного ока", які $\epsilon$ патогномонічною ознакою цитомегаловірусної пневмонії. Інший приклад - у просвітах альвеол можна спостерігати еозинофільний пінистий білковий ексудат, який характерний для ПП [2].

Тобто, клініко-морфологічна діагностика інфекційних ускладнень при ВІЛ-інфекції на теперішній час дозволяє виявляти цитомегаловірусну інфекцію, токсоплазмоз, пневмоцистоз, кандидоз, криптококоз, ТБ, але слід пам'ятати про високу ймовірність розвитку й багатьох інших клінічно 
Огляди літератури, оригінальні дослідження, погляд на проблему, випадок з практики, короткі повідомлення значущих інфекцій. В умовах нашої країни це, перш за все, атиповий мікобактеріоз, хламідіоз та мікоплазмоз. На тлі прогресування імунодефіциту відбувається різке зростання частоти їх клінічної маніфестації [22]. На жаль, діагностика цих інфекцій можлива лише за мікробіологічним дослідженням, чіткі морфологічні критерії відсутні.

Одним із головних завдань, які вирішує патологоанатомічна служба, є зіставлення клінічного та патологоанатомічного діагнозу. І важливо відмітити, що навіть у переважній кількості випадків ТБ, асоційованого з ВІЛ-інфекцією, навіть при формальному збігу цих діагнозів за основним процесом, практично завжди заключний клінічний діагноз уточнюється та доповнюється, часто - досить суттєво [23]. Наші результати повністю підтверджують цей факт. А саме, окрім уточнення клінікоморфологічної форми ТБ легень, виконане комплексне гістохімічне дослідження уточнило діагноз у 6 (19,4 \%) випадках, а в 3 (9,7 \%) випадках повністю змінило попередній клінічний діагноз підозри наявності туберкульозної інфекції.

На завершення можна зазначити, що багато як теоретичних, так і практичних аспектів перебігу ВІЛ-інфекції в асоціації з різними іншими вторинними інфекціями потребують подальшого комплексного дослідження з обов'язковим морфологічним аналізом.

Висновки. 1. При проведенні морфологічної діагностики у ВІЛ-інфікованих пацієнтів із вто-

\section{ЛІТЕРАТУРА}

1. Константинова А. М. Криптококкоз при ВИЧинфекции / А. М. Константинова // Вестник СанктПетербургского университета. - 2010. - Сер. 11, вып. 3. C. 37-44.

2. Тимченко О. А. Значение гистологического метода исследования в диагностике ВИЧ-ассоциированных инфекций / О. А. Тимченко, Е. И. Журавлева, А. А. Иванов // Судебная медицина. - 2017. - Т. 3, № 3. C. $42-45$.

3. Лекции по ВИЧ-инфекции / под ред. В. В. Покровского. - М. : ГЭОТАР-Медиа, 2-е изд., перера6. и доп., 2018. -848 с.

4. Пузырева Л. В. Заболевания органов дыхания при ВИЧ-инфекции (обзор) / Л. В. Пузырева, А. Д. Сафонов, А. В. Мордык // Журнал инфектологии. - 2016. T. 8, № 2. - С. 17-25.

5. Анализ инфекций нижних дыхательных путей с исследованием микробного пейзажа материала у ВИЧинфицированных пациентов / Л. В. Пузырева, Л. А. Родькина, А. В. Мордык [и др.] // Журнал микробиологии. 2018. - № 1. - С. 76-84.

6. Цико О. В. Легеневі ураження у ВІЛ-позитивних осіб (короткий огляд) / О. В. Цико, В. М. Козько // Актуальна інфектологія. - 2018. - Т. 6, № 6. - С. 320-326.

ринними інфекційними ураженнями органів грудної порожнини доцільне застосування низки спеціальних гістохімічних методів дослідження уражених тканин з метою виявлення як КСБ або антигенів МБТ, так і елементів грибкової мікрофлори.

2. Рутинне гістологічне дослідження препаратів, забарвлених гематоксиліном і еозином, у більшості діагностичних випадків не забезпечує повної морфологічної діагностики вторинної інфекції уражених органів грудної порожнини при ВІЛ-інфекції. За нашими даними, у 67,7 \% досліджень при розширеному морфологічному дослідженні із застосуванням низки різних методів, початковий патогістологічний висновок був уточнений або повністю змінений.

3. Загальна ефективність комплексного морфологічного дослідження Серед ВІЛ-інфікованих хворих з інфекційним ураженням органів грудної порожнини та підозрою на наявність бактеріально-грибкової інфекції склала 93,5 \%.

Перспективи подальших досліджень полягають у впровадженні в гістологічне дослідження уражених тканин органів грудної порожнини від ВІЛ-інфікованих хворих сучасних методик виявлення мікроорганізмів у разі інфекційного процесу та розробці нових методів діагностики інфекційної патології.

Робота виконана за рахунок коштів державного бюджету.

7. Гранитов В. М. ВИЧ-инфекция/СПИД, СПИД-ассоциированные инфекции и инвазии / В. М. Гранитов. М. : Медицин. книга, 2003. - 124 с.

8. Комаровская Е. И. Проблемы диагностики легочного криптококкоза. Клинический случай / Е. И. Комаровская, М. Е. Павлов, Е. А. Климова // Инфекционные болезни: новости, мнения, обучение. - 2014. - №3. C. $72-76$.

9. Пархоменко Ю. Г. Дифференциальная диагностика деструктивных поражений легких при ВИЧ-ассоциированных инфекциях / Ю. Г. Пархоменко, Ю. Р. Зюзя, Д. М. Флигиль // Архив патологии. - 2011. - № 5. - С. 9-12.

10. Шкарин В. В. Эпидемиология оппортунистических микозов / В. В. Шкарин, Н. В. Саперкин // Вестник дерматологии и венерологии. - 2017. - № 3. - С. 21-31.

11. Чарушина И. П. Оппортунистические инвазивные микозы у ВИЧ-инфицированных пациентов / И. П. Чарушина // Пермский медицинский журнал. 2015. - T. XXXII, № 1. - С. 71-77.

12. Хэм Л. Гистология / Л. Хэм, Д. Кормак. - М. : Мир. - 1982. - С. 35-37.

13. Коржевский Д. Э. Основы гистологической техники / Д. Э. Коржевский, А. В. Гиляров. - СПб. : СпецЛит, 2010. - С. 63-64. 
Огляди літератури, оригінальні дослідження, погляд на проблему, випадок з практики, короткі повідомлення

14. Greenwood N. A comparison of methods for staining tubercle bacilli in histological sections / N. Greenwood / J. Clin. Path. - 1973. - No. 26. - P. 253-257.

15. Методы гистологической окраски. - ООО «БиоВитрум", 2009. - С. 7, 22.

16. Bancroft J. D. Theory and practice of histological techniques / J. D. Bancroft. - Elsevier, 6th edition, 2008. P. 409-410.

17. Carson F. L. Histotechnology: A self-Instuctional Text / F. L. Carson. - Chicago: ASCP Press, 2nd Edition, 1997. $-400 \mathrm{p}$.

18. Петров С. В. Руководство по иммуногистохимической диагностике опухолей человека / С. В. Петров, Н. Т. Райхлин. - Казань, 2012. - 623 с.

19. Пархоменко Ю. Г. Патологоанатомическая диагностика ВИЧ-ассоциированных инфекций : методические рекомендации / Ю. Г. Пархоменко, Ю. Р. Зюзя. Москва, 2012. - 72 с.

\section{REFERENCES}

1. Konstantinova, A.M. (2010). Kriptokokkoz pri VIChinfektsii [Cryptococcosis in HIV infection]. Vestnik SanktPeterburgskogo universiteta - Bulletin of Saint Petersburg University, 11 (3), 37-44 [in Russian].

2. Timchenko, O.A., Zhuravleva, E.I., \& Ivanov, A.A. (2017). Znacheniye gistologicheskogo metoda issledovaniya $v$ diagnostike VICh-assotsiyrovannykh infektsiy [The importance of a histological method of research in the diagnosis of HIV-associated infections]. Sudebnaya meditsina - Forensic Medicine, 3 (3), 42-45 [in Russian].

3. Pokrovskiy, V.V. (Ed.). (2018). Lektsii po VICh-infektsii [Lectures on HIV infection]. Moscow: GEOTAR-Media [in Russian].

4. Puzyreva, L.V., Safonov, A.D., \& Mordyk, A.V. (2016) Zabolevaniya organov dykhaniya pri VICh-infektsii (obzor) [Diseases of respiratory organs at HIV infection (review)]. Zhurnal infektologii - Journal of Infectology, 8 (2), 17-25 [in Russian].

5. Puzyreva, L.V., Rodkina, L.A., Mordyk, A.V., Konchenko, V.D., \& Dalabayeva, L.M. (2018). Analiz infektsiy nizhnikh dykhatelnykh putey s issledovaniyem mikrobnogo peyzazha materiala u VICh-infitsirovannykh patsiyentov [Analysis of lower respiratory tract infections with a research of a microbial landscape of material at HIV-positive patient]. Zhurnal mikrobiologii - Journal of Microbiology, 1, 76-84 [in Russian].

6. Tsyko, O.V., \& Kozko, V.M. (2018) Lehenevi urazhennia u VIL-pozytyvnykh osib (korotkyi ohliad) [Pulmonary lesions in HIV-positive persons (brief review)]. Aktualna infektolohiia - Actual Infectology, 6 (6), 320-326 [in Ukrainian].

7. Granitov, V.M. (2003). VICh-infektsiya/SPID. SPIDassotsiirovannyye infektsii $i$ invazii [HIV infection / AIDS, AIDS-related infections and infestations]. Moscow: Meditsin. kniga [in Russian].

8. Komarovskaya, E.I., Pavlov, M.E., \& Klimova, E.A. (2014). Problemy diagnostiki legochnogo kriptokokkoza. Klinicheskiysluchay [Problems ofpulmonary cryptococcosis diagnostics. The clinical case]. Infektsionnyye bolezni:
20. Диагностика и клиника диссеминированных поражений легких у больных на поздних стадиях ВИЧинфекцией с иммуносупрессией (обзор) / А. В. Мишина, В. Ю. Мишин, А. Э. Эргешов, В. В. Романов // Журнал поликлиника. - 2019. - № 2 (14). - С. 13-21.

21. Викторова Е. А. Патоморфологические изменения при СПИД-ассоциированных заболеваниях с поражением органов дыхания / Е. А. Викторова, О. В. Азовцева // Международный журнал медицины и психологии. - 2019. - Т. 2, № 3. - С. 74-80.

22. Цинзерлинг В. А. Важнейшие проблемы морфологической диагностики при ВИЧ-инфекции / В. А. Цинзерлинг // ВИЧ-инфекция и иммуносупрессии. - 2009. Т. 1, № 2. - С. 31-37.

23. Цинзерлинг В. А. ВИЧ-инфекция и туберкулез. Проблемы клинико-морфологических сопоставлений / В. А. Цинзерлинг // Медицинский академический журнал. - 2013. - Т. 13, № 4. - С. 87-91.

novosti, mneniya, obucheniye - Infectious Diseases: News, Opinions, Training, 3, 72-76 [in Russian].

9. Parkhomenko, Yu.G., Zyuzya, Yu.R., \& Fligil, D.M. (2011). Differentsialnaya diagnostika destruktivnykh porazheniy legkikh pri VICh-assotsiirovannykh infektsiyakh [Differential diagnosis of the destructive lung changes in HIVassociated infections]. Arkhiv patologii - Archive of Pathology, 5, 9-12 [in Russian].

10. Shkarin, V.V., \& Saperkin, N.V. (2017). Epidemiologiya opportunisticheskikh mikozov [Epidemiology opportunistic mycoses]. Vestnik dermatologii i venerologii - Vestnik of Dermatology and Venerology, 3, 21-31 [in Russian].

11. Charushina, I.P. (2015). Opportunisticheskiye invazivnyye mikozy u VICh-infitsirovannykh patsiyentov [Opportunistic invasive mycoses in HIV-infected patients]. Permskiy meditsinskiy zhurnal - Perm Medical Journal, XXXII (1), 71-77 [in Russian].

12. Khem, L., \& Kormak, D. (1982). Gistologiya [Histology]. Moscow: Mir [in Russian].

13. Korzhevskiy, D.E., \& Gilyarov, A.V. (2010). Osnovy gistologicheskoy tekhniki [Basics of histological technique]. SPb.: SpetsLit [in Russian].

14. Greenwood, N. (1973). A comparison of methods for staining tubercle bacilli in histological sections. J. Clin. Path., 26, 253-257.

15. (2009). Metody gistologicheskoy okraski [Methods of histological staining]. OOO "BioVitrum" [in Russian].

16. Bancroft, J.D. (2008). Theory and practice of histological techniques. Elsevier.

17. Carson, F.L. (1997). Histotechnology: A self-Instuctional Text. Chicago: ASCP Press.

18. Petrov, S.V., \& Raykhlin, N.T. (2012). Rukovodstvo po immunogistokhimicheskoy diagnostike opukholey cheloveka [Guidelines for the immunohistochemical diagnosis of human tumors]. Kazan [in Russian].

19. Parkhomenko, Yu.G., \& Zyuzya, Yu.R. (2012). Patologoanatomicheskaya diagnostika VICh-assotsiirovannykh infektsiy: Metodicheskiye rekomendatsii [Pathological diagnosis of HIV-associated infections: Guidelines]. Moscow [in Russian]. 
Огляди літератури, оригінальні дослідження, погляд на проблему, випадок з практики, короткі повідомлення

20. Mishina, A.V., Mishin, V.Yu., Ergeshov, A.E., \& Romanov, V.V. (2019). Diagnostika i klinika disseminirovannykh porazheniy legkikh u bolnykh na pozdnikh stadiyakh VICh-infektsiyey s immunosupressiyey (obzor) [Diagnosis and clinic of disseminated lung lesions in patients with advanced HIV infections with immunosuppression (review)]. Zhurnal poliklinika - Journal Clinic, 2 (14), 13-21 [in Russian].

21. Viktorova, E.A., \& Azovtseva, O.V. (2019). Patomorfologicheskiye izmeneniya pri SPID-assotsiirovannykh zabolevaniyakh s porazheniyem organov dykhaniya [Pathological changes in AIDS-associated diseases with the respiratory system disorders]. Mezhdunarodnyy zhurnal meditsiny i psikhologii - International Journal of Medicine and Psychology, 2 (3), 74-80 [in Russian].

22. Tsinzerling, V.A. (2009). Vazhneyshiye problemy morfologicheskoy diagnostiki pri VICh-infektsii [Main problems of morphological diagnostics of HIV-infection]. VICh-infektsiya i immunosupressii - HIV Infection and Immunosuppressive, 1 (2), 31-37 [in Russian].

23. Tsinzerling, V.A. (2013.) VICh-infektsiya i tuberkulez. Problemy kliniko-morfologicheskikh sopostavleniy [HIV infection and Tuberculosis. Problems of clinico-pathological correlations]. Meditsinskiy akademicheskiy zhurnal Medical Academic Journal, 13 (4), 87-91 [in Russian].

\title{
МОРФОЛОГИЧЕСКАЯ ДИАГНОСТИКА ИНФЕКЦИОННЫХ ПОРАЖЕНИЙ СРЕДИ ВИЧ-ИНФИЦИРОВАННЫХ ПАЦИЕНТОВ С ПАТОЛОГИЕЙ ОРГАНОВ ГРУДНОЙ ПОЛОСТИ
}

\author{
๑И. В. Лискина, О. А. Мельник, Л. М. Загаба, С. Д. Кузовкова, А. Л. Мельник
}

Государственное учреждение «Национальный институт фтизиатрии и пульмонологии имени Ф. Г. Яновского НАМН Украины», Киев

РЕЗЮМЕ. ВИЧ-инфекция характеризуется постоянно возрастающим количеством лиц с оппортунистическими заболеваниями и ростом летальности от них. Частота развития заболеваний органов дыхания - более $60 \%$, при этом чаще всего диагностируется туберкулез. Диагностические возможности в отношении оппортунистических болезней остаются ограниченными. Кроме того, сейчас более чем у 50 \% пациентов имеет место сочетание различных вторичных заболеваний, что сопровождается возрастанием тяжести их течения, проблем диагностики и лечения.

Цель-установить диагностическую эффективность комплексного использования различных методов гистологического исследования для верификации этиологии инфекционных поражений органов грудной полости на фоне ВИЧ-инфекции.

Материал и методы. Группу исследования составил 31 случай вторичных инфекционных поражений органов грудной полости у ВИЧ-инфицированных больных. Прежде всего, выполняли традиционное гистологическое исследование. Дополнительно применяли гистохимические методики: Циль - Нильсен, флуоресцентный метод, метод Гомори - Гроккота и ШЙК-реакцию с альциановым синим, а также иммуногистохимическое исследование по выявлению микобактериальных антигенов с двумя поликлональными антителами к M. tuberculosis.

Результаты. По результатам комплексного гистологического исследования диагностировано 15 (48,4 \%) случаев туберкулезного процесса. Сопоставление предварительного и заключительного клинических диагнозов всех случаев нашего исследования показало, что лишь в 3 случаях (9,7 \%) получено подтверждение предварительного клинического диагноза, в 9 случаях (29,0\%) клинический диагноз был уточнен и в 12 случаях (38,7 \%) установлен диагноз. Еще в 5 случаях (16,1 \%) предварительный клинический диагноз оказался ошибочным и был изменен. И только в 2 (6,5 \%) случаях окончательный диагноз не был установлен. Таким образом, в 25 случаях $(80,6 \%)$ установлено развитие грибковой инфекции и в 15 случаях $(48,4 \%)$ диагностирован туберкулез. Всего в 16 (51,6 \%) случаях выявлены ассоциации различных вторичных инфекций.

Выводы. В процессе морфологической диагностики у ВИЧ-инфицированных пациентов с вторичными инфекционными поражениями органов грудной полости целесообразно использование ряда специальных гистохимических методов исследования пораженных `тканей. В 67,7 \% случаев при расширенном морфологическом исследовании начальный патогистологический вывод был уточнен или полностью изменен. Общая эффективность комплексного морфологического исследования составила 93,5 \%.

КЛЮЧЕВЫЕ СЛОВА: ВИЧ-инфекция; туберкулез; оппортунистические заболевания; гистологическое исследование; диагностика. 

PATIENTS WITH THORACIC PATHOLOGY

\author{
@I. V. Liskina, O. A. Melnyk, L. M. Zahaba, S. D. Kuzovkova, O. L. Melnyk \\ F. Yanovsky National Institute of Phthisiology and Pulmonology, NAMS of Ukraine
}

SUMMARY. HIV infection is associated with an ever-increasing number of people with opportunistic diseases and an increasing mortality from them. The incidence of respiratory diseases is more than $60 \%$, while tuberculosis is most often diagnosed. Diagnostic options regarding opportunistic diseases remain limited. In addition, now more than $50 \%$ of patients have an association of various secondary diseases, which leads to an increase in the severity of their course, problems of diagnosis and treatment.

The aim - to establish the diagnostic effectiveness of the integrated use of various histological methods to verify the etiology of infectious lesions of thorax associated with HIV infection.

Material and Methods. The study included of 31 cases of secondary infectious lesions of the thorax in HIV-infected patients. First of all, a traditional histological examination was performed. In addition, histochemical methods were used: Ziel-Nielson method, fluorescence method, Gomori-Groccott's method and PAS-reaction with alcian blue, and immunohistochemical studies to detect mycobacterial antigens with two polyclonal antibodies to M. tuberculosis.

Results. According to the results of a comprehensive histological examination, $15(48.4 \%)$ cases of the tuberculosis were diagnosed. Comparison of the preliminary and final clinical diagnosis of all cases of our study showed, that only 3 cases $(9.7 \%)$ received confirmation of the preliminary clinical diagnosis, in 9 cases $(29.0 \%)$ the clinical diagnosis was clarified and in 12 cases (38.7\%) the diagnosis is established. In another 5 cases (16.1\%), the preliminary clinical diagnosis was wrong and was changed. And only in 2 (6.5\%) cases the final diagnosis was not established. Thus, in 25 cases $(80.6 \%)$ the development of a fungal infection was established and in 15 cases (48.4 \%) tuberculosis was diagnosed. Overall in 16 (51.6 \%) cases there were revealed associations of various secondary infections.

Conclusions. When conducting morphological diagnostics in cases of HIV-infected patients with secondary infectious lesions of the thorax, it is advisable to use a number of special histochemical methods for examining the affected tissues. In $67.7 \%$ cases with an extended morphological study, the initial histopathological conclusion was clarified or completely changed. The overall effectiveness of a comprehensive morphological study was $93.5 \%$.

KEY WORDS: HIV infection; tuberculosis; opportunistic diseases; histological examination; diagnosis. 